\title{
Confrontations with Death: Psychological Responses During Internship
}

Michael Miller, M.D.

Institute of Pennsylvania Hospital, Philadelphia

Follow this and additional works at: https://jdc.jefferson.edu/jeffjpsychiatry

Part of the Psychiatry Commons

Let us know how access to this document benefits you

\section{Recommended Citation}

Miller, M.D., Michael (1989) "Confrontations with Death: Psychological Responses During Internship," Jefferson Journal of Psychiatry. Vol. 7 : Iss. 2 , Article 12.

DOI: https://doi.org/10.29046/JJP.007.2.010

Available at: https://jdc.jefferson.edu/jeffjpsychiatry/vol7/iss2/12

This Article is brought to you for free and open access by the Jefferson Digital Commons. The Jefferson Digital Commons is a service of Thomas Jefferson University's Center for Teaching and Learning (CTL). The Commons is a showcase for Jefferson books and journals, peer-reviewed scholarly publications, unique historical collections from the University archives, and teaching tools. The Jefferson Digital Commons allows researchers and interested readers anywhere in the world to learn about and keep up to date with Jefferson scholarship. This article has been accepted for inclusion in Jefferson Journal of Psychiatry by an authorized administrator of the Jefferson Digital Commons. For more information, please contact: JeffersonDigitalCommons@jefferson.edu. 


\title{
Confrontations With Death: Psychological Responses During Internship
}

\author{
Michael Miller, M.D.
}

During internship, the daily confrontation with the consequences of disease contributes much to the distress which young physicians experience (1). Not only are interns responsible for first line medical care, they must also provide emotional support for their patients struggling with pain, disability and impending death. This paper seeks to examine some of the factors responsible for the turmoil involved in caring for these dying patients.

Our conceptions of death and dying are determined to a large extent by the cultural context in which we live. Compared with other times in which death was not so ego alien, we presently live in a time and culture which Aries has called "death-denying" (2). Eissler has suggested that "death is one of those unsavory facts which cannot be integrated into (our present), essentially hedonistic civilization ... (It) must therefore remain a foreign body, denied by silence rather than recognized as the possible Alpha and Omega of life itself' (3).

Furthermore, as children, today's physicians are less exposed to death and dying than ever before in human history (4). The reasons for this are numerous. Improvements in public health have dramatically lowered infant mortality rates and advances in medical care have helped extend the average life expectancy into the seventh decade. Changes in family structure have resulted in a reduction of homes housing three generations together. The deaths of family elders, once experienced by the group at large, are now segregated, both physically and emotionally, from younger family members (4). In the past most people died at home surrounded by family. Now, most deaths take place in hospitals unwitnessed. In addition, physicians our age have been spared the nightmare of war which for many previous generations provided exposure to the realities of death.

Our relatively limited personal experience renders most of us ill prepared to help patients deal with these concerns. Medical education has traditionally done little to address this deficiency (5). The social and psychological aspects of death and dying are often neglected in medical school or are relegated to low priority elective courses (5).

Medical education's failure to help young physicians feel comfortable with dying patients or their families may make it difficult for them to function in one of our profession's most central roles (6). When our own anxiety about death and dying is too great we may make it impossible for our patients to share their concerns with us. Cassilith explains that if these patients are cut off from meaningful communication with others they are "denied the relief that the act 
of sharing one's concerns and feelings typically brings. An unwillingness or inability to talk about death, or to allow patients to do so, contributes to the fear of abandonment that, along with fears of pain, represents dying patients' most prevalent concern" (7).

In the hospital death is a ubiquitious phenomenon and rather than preserve life, physicians are often called to preside over its conclusion. Since DRGs make it difficult to admit other than very ill patients, the proportion of patients whom interns must care for with serious or life threatening conditions is high. The AIDS epidemic alone is responsible for the growing numbers of young adults who are admitted to the hospital with frightening and fatal diseases. It is not unusual for an intern to carry a service of eight to twelve patients, one third or more of whom are terminally ill.

The psychological effect of caring for dying patients is profound; death is a reality which all human beings attempt to deny. In his thought provoking and widely influential book, The Denial of Death. Ernest Becker asserts, "The idea of death, the fear of it, haunts the human animal like nothing else; it is a mainspring of human activity - activity designed largely to avoid the fatality of death, to overcome it by denying in some way that it is the final destiny for man" (8).

Weisman explains how the care of the dying arouses other fears as well, such as, "extinction, victimization, helplessness, passivity, abandonment, disfigurement, and, above all, loss of self-esteem. The physician who undertakes to treat these patients . . . is also subject to these fears. Since he is bound to a patient who will die, physicians must also face an exacerbation of his own sense of failure, guilt, and intimations of personal mortality"' (9).

Physicians who work with dying patients must protect themselves against the anxieties which invariably arise or risk psychic exhaustion. Pattison elaborates, "We can only work with dying persons for so long, and with so much personal investment, and with so much intensity, before we have reached the limits of our own personal tolerance. Helping the dying is a personally demanding task ... . we must be able to identify our personal limits of saturation and recognize that our human spirits get exhausted too. It is unrealistic to demand of ourselves the ability to face dying all the time on an intense basis and expect to survive psychically" (10).

Most of us survive internship but frequently with emotional costs. This problem is accentuated by the fact that interns do not have the "luxury" of taking time out for emotional reconstitution. The result of our training system which does not provide time and space for emotional reprieves is that our psychic defenses attempt to do this for us with "denial, callousness, emotional withdrawal, disinterest, and so on," which Pattison recognizes "as the unfortunate manifestations of psychic exhaustion" (10).

One of the adaptive ways physicians defend against anxiety and exhaustion is through a preoccupation with academic concerns in medicine. This enables us to focus our attention on objective issues and helps us to avoid thinking about the existential realities our patients are facing. In addition, it may be that our 
intellectual fascination with disease renders it less threatening. If pathology is exciting then perhaps it is not something to fear.

The other arena in which young adults confront death regularly is in combat situations. In war, however, the threat to one's own survival is real and not just feared. How soldiers function in the face of their anxiety over death offers an interesting contrast to medicine. In writing on the psychology of war Zilboorg postulates that soldiers are only able to function by converting their death anxiety into "murderous hatred of the enemy" (11). This psychic conversion also serves to bolster morale among troops fighting a common enemy.

In medicine, however, there is no agent for doctors to hate. Our death anxiety cannot simply be converted into aggression. The only enemy doctors confront is the pathology of disease. Not only is this too intangible to hate, it is something which intersects us. After all, there is nothing many physicians dislike more than the patient with whom there is nothing physically wrong.

Our preoccupation with pathology may serve another function as well. Although speculative, it may be that our unconscious sadistic tendencies are gratified by the exposure to the terrible realities we witness in the hospital. This may help us tolerate the pain, mutilation and death we encounter in our work with ill and dying patients.

Often we are unable to alter the inexorability of nature's course and are unable to cure our patients of their illnesses. If we become too invested in their outcomes we risk injury to our self esteem and are vulnerable to depression, self recrimination, guilt and anger. These unpleasant feelings may lead us to respond aggressively by overtreating disease. When we have passed the point of prolonging life to where we are only prolonging dying, we may be acting out our own aggression against the patient. Despite the seemingly paradoxical nature of this statement, this remains one of the ways in which our unconscious anger forces patients to suffer longer than need be.

Frequently, families conspire with attendings in prolonging the lives and the agony of their loved ones. This is done not only out of love and responsibility, but sometimes out of guilt as well. This guilt may arise for many reasons. Often people feel guilty about negative feelings they may have for their loved ones who are dying. The unacceptability of these negative feelings may be defended against with reaction formation and the demand to employ heroic measures. Such action may be a way of actually avoiding responsibility for our patients. We may then be criticized for side-stepping the issues involved in making reasoned, humane suggestions about when it is time to stop, and when it is natural to die.

All physicians must come to terms with their limitations and challenge what Feldman has called the "cult of curability" (12). We must learn to accept the inevitability of a patient's death and better understand our own responses to it. We need to learn how to transform what feels like defeat into a meaningful and positive experience. Mount argues that physicians must adapt to a "metamorphosis in the role from curer to life-prolonging champion of the fight against disease to sustainer when nothing else can be done ... the issue is not to treat or not to 
treat, but rather the evolution in the nature of interventions that will be most helpful"' (13).

Internship provided an opportunity for those of us in psychiatry to serve dying patients as medical caretakers. Most of us are unlikely to work in this capacity during our professional careers again. As psychiatrists, however, we will have many opportunities to serve as consultants, educators, and as friends to help make the process of dying more humane.

\section{REFERENCES}

1. McCue JD: The distress of internship. NEJM 312(7):449-452, 1985

2. Aries P: Western Attitudes Towards Death: From the Middle Ages to the Present. Baltimore, Johns Hopkins, 1974

3. Eissler KR: The Psychiatrist and the Dying Patient. New York, International Universities Press, 1955

4. Kerstein MD: Help for the young physician with death and grieving, in Psychosocial Care of the Dying Patient, ed. Garfield CA, New York, McGraw Hill, p. 100-101, 1978

5. Dickinson GE: Changes in death education in US medical schools during 19751985. Journal of Medical Education 60:942-943, 1985

6. Dickinson GE and Pearson AA: Death education and physicians' attitudes toward dying patients. Omega 11:167-174, 1980-1981

7. Cassileth BR: Care of the terminally ill patient and family. Delaware Medical Journal 55:481-486, 1983

8. Becker E: The Denial of Death, New York, The Free Press, 1973

9. Weisman AD: Misgivings and misconceptions in the psychiatric care of terminal patients. In Psychosocial Care of the Dying Patient, op. cit., p. 185-200

10. Pattison EM: The living dying process. In Psychosocial Care of the Dying Patient, op. cit., p. 185-200

11. Zilboorg G: Fear of death. The Psychoanalytic Quarterly 12:465-475, 1943

12. Feldman A: The dying patient. Psychiatric Clinics of NA: 10(1):101-108, 1987

13. Mount BM: Dealing with our losses. Journal of Clinical Oncology 4:1127-1134, 1986 